УДК 331.101.262:656.2

\title{
ДОСЛІДЖЕННЯ ТА УДОСКОНАЛЕННЯ СТРАТЕГІЇ ВПРОВАДЖЕННЯ СУЧАСНИХ МЕТОДІВ ОЦІНКИ ТА ВІДБОРУ ПЕРСОНАЛУ
}

Д-р екон. наук В.В. Дикань, магістрант Ю.О. Шаповалов

\section{ИССЛЕДОВАНИЕ И УСОВЕРШЕНСТВОВАНИЕ СТРАТЕГИИ ВНЕДРЕНИЯ СОВРЕМЕННЫХ МЕТОДОВ ОЦЕНКИ И ПОДБОРА ПЕРСОНАЛА}

\author{
Д-р экон. наук В.В. Дикань, магистрант Ю.А. Шаповалов
}

\section{RESEARCH AND IMPROVEMENT OF THE STRATEGY FOR INTRODUCING MODERN METHODS OF ASSESSMENT AND SELECTION OF THE PERSONNEL}

\begin{abstract}
Doct. of ekon. sciences V.V. Dykan, master student Y.O. Shapovalov
Стаття присвячена вирішенню проблем пошуку шляхів удосконалення впровадження сучасних методів очінки та відбору персоналу на підприємствах промислової галузі. Доведено важливу роль промислових підприємств в господарчому комплексі країни та їх значення у здійсненні внутрішньодержавних та зовнішньодержавних економічних зв'язків. Проаналізовано існуючі форми та методи управління персоналом на підприємствах, визначено роль та завдання систем мотивачії персоналу на иляху підвищення продуктивності праці на підприємствах промислової галузі держави.
\end{abstract}

Ключові слова: персонал, мотивачія, ефективність діяльності, трудова діяльність, трудовий потенціал, концеепџія управління.

The article is devoted to the solution of the problems of ways of improving the introduction of modern methods of assessment and selection of personnel at the industrial enterprises. It is proved that the industrial enterprises play an important role in the national economics as well as in the development of the domestic and international economic relations. The focus of the article is on the analysis of the present forms and methods of the management of the personnel at the enterprises with outlining the role and the aim of the system of motivation of the personnel for increasing the productivity of labourat the industrial enterprises.

Keywords: personnel, motivation, productivity of labour, labour activity, the notion of management

Статья посвящена решению проблем путей усовершенствования внедрения современных методов оченки и отбора персонала на предприятиях промышленной отрасли. Доказана важная роль промышленных предприятий в хозяйственном комплексе страны $и$ их значение в осуществлении внутригосударственных $u$ внешнегосударственных экономических связей. Проанализированы существующие формы и методы управления персоналом на предприятиях, определена роль и задачи систем мотивачии персонала на пути повышения продуктивности труда на предприятиях промышленной отрясли государства.

Ключевые слова: персонал,мотивачия, эффективность деятельности, трудовая деятельность, концепция управления.

Вступ.

В умовах становлення сучасної економіки особливе значення мають питання практичного використання ринкових форм управління персоналом на промислових підприємствах, які повинні сприяти підвищенню розвитку трудового потенціалу підприємства.

Як відомо трудовий потенціал - це сукупність здібностей і можливостей кадрів забезпечувати досягнення цілей 
довгострокового (перспективного) розвитку підприємства. Саме тому сучасна концепція управління підприємством передбачає,виділення 3 величезної кількості функціональних сфер управлінської діяльності тієї, яка пов'язана $з$ управлінням кадровою складовою виробництва персоналом підприємства.

Постановка проблеми у загальному вигляді та іiі зв'язок із важливими науковими та практичними завданнями.

У сучасних умовах в країні постає питання реформування промислових підприємств як базової галузі економіки нашої держави. На порядку денному можливі варіанти зміни частково форми власності та коригування адміністративнокомандних методів управління підприємствами. Зазначене потребує не тільки використання в процес і управління підприємством сучасних економічних досліджень, розроблення бізнес планів, використання методології стратегічного планування, а й інших необхідних атрибутів ринкової економіки. Цьому повинно передувати поглиблене вивчення теоретичних та методологічних положень, закономірностей i принципів науки i практики управління,часткове залучення щодо оцінки та відбору персоналу, а також мотиваційних систем які сприятимуть підвищенню ефективності трудового потенціалу підприємств промислової галузі.

Аналіз останніх досліджень і публікацій.

Теоретичні основи ефективного використання трудового потенціалу на базі концепцій якості трудового життя, методів стимулювання та мотивації праці, питання визначення сутності та структури трудового потенціалу представлені в роботах таких вітчизняних i зарубіжних вчених, якВ. Адамчук, П. Друкер, М. Альберт, Х. Ширенбек, Є. Касимовський, Р. Ккаплан, Е. Лоулер, Д. Маркович, А. Маслоу, М. Мескон, Г. Погосян, О. Ромашов, Л. Спенсер, С. Чижова та ін.

Значний внесок у розробку прикладних теоретико-методологічних проблем трудового потенціалу вносять сучасні російські та українські вчені: М.
Бажанова, 3. Бараева, М. Бухалков, Б. Генкін, B. Горбань, Т. Давидюк, В. Довгий, Є. Колесень, Х. Ксенофонтова, А. Кібанов, О. Кузьмін, Є. Маслов, А. Нікітін, Ю. Одєгов, В. Потуданська, С. Радько, Л. Трункіна, Т. Хлопова, Н. Шаталова.

Питання оцінки трудового потенціалу підприємства, мотивації працівників залізничного транспорту досліджені в наукових працях В. Диканя, Д. Ейтутіса, Ю. Слагіна, О. Казаку, В. Козирєва, В. Компанієць, I. Назаренко, О. Пруднікова, Б. Смирнова, Т. Сухорукової, В. Токарєва, Л. Шкуріної та інших вчених.

\section{Визначення мети та задачі дослідження.}

Кардинальні зміни що мають місце в умовах реалізації концепції державної програми реформування промислової галузі, потребують додаткових досліджень саме 3 питань розробки стратгій впровадження сучасних методів оцінки та відбору персоналу на промислових підприємствах, а також розробки методів мотивації для підвищення ефективності трудового потенціалу підприємства. Саме цей аспект $\epsilon$ предметом дослідження, що покладено в основу запропонованої публікації.

Метою передбачуванних дослідженьє розкриття сутності ефективності управлінської діяльності в країні та на промисловому підприємстві ТОВ «МОСПІНСЬКЕ ВПП» а також пошук недоліків в стратегії впровадження сучасних методів оцінки та відбору персоналу з точки зору шляхів їх подолання.

Дослідження зазначених питань формує комплекс задач, які мають включити наступне:

- визначення сутності економічної категорії «трудовий потенціал» на підприємстві ТОВ «МОСПІНСЬКЕ ВПП»;

- аналіз методів підбору, оцінки та відбору персоналу на підприємстві;

- узагальнення досвіду формування i розвитку стратегії впровадження сучасних методів оцінки та відбору персоналу на підприємстві;

- аналіз практики методів відбору та оцінки трудового потенціалу на ТОВ «МОСПІНСЬКЕ ВПП»; 
- розроблення

рекомендацій 3 дослідження мотивів працівників;

- розроблення методичних засад використання KPI для удосконалення системи мотивації персоналу.

\section{Основна частина дослідження.}

На керівництво людьми та прийняття кадрових рішень керівники витрачають більше часу ніж на виконання всіх інших обов'язків [1, с.62].

Звичайно невеликими підприємствами керівники управляють, як правило самостійно. Процес управління великим підприємством відбувається в інших умовах. В управлінській системі таких підприємств зайняті десятки, а іншим разом i сотні людей. Процес управління в такому випадку має бути організований належним чином. Все це потребує від керівників на всіх рівнях адекватної організації процесу управління, яка повинна забезпечити максимально ефективне управління підприємством при мінімальних витратах.

В умовах становлення сучасної економіки особливе значення мають питання практичного використання ринкових форм управління персоналом на промислових підприємствах, які повинні сприяти підвищенню розвитку ефективності трудового потенціалу будь якого підприємства.

Як відомо трудовий потенціал - це сукупність здібностей і можливостей кадрів забезпечувати досягнення цілей довгострокового (перспективного) розвитку підприємства [4 c.112-113]. Саме тому сучасна концепція управління підприємством передбачає,виділення 3 величезної кількості функціональних сфер управлінської діяльності тієї, яка пов'язана 3 управлінням кадровою складовою виробництва - персоналом підприємства [2 c.80-81].

Проте кадрові рішення як правило виявляються самими складними і самими важливими в довгостроковій перспективі, тому існує ряд проблем, які стають на заваді ефективного розвитку та управління кадровим потенціалом у промисловій галузі.
Основною з цих проблем $\epsilon$ якість робочої сили та іiї кваліфікаційний рівень.

Враховуючи демографічну ситуацію в нашій країні, стає можливим зробити висновки, що найбільшим часом наша держава не зможе вирішувати економічні проблеми за рахунок лише простого нарощування чисельності зайнятого населення. В умовах ринкової економіки усе більшого значення набувають саме якісні характеристики трудового потенціалу: кваліфікація, професіоналізм, здатність до отримання знань у продовж життя,рівень культури тощо. Крім того стрімкий розвиток науки i техніки потребує від учасників трудового процесу постійного самовдосконалення. Тому рішення кадрових проблем самі важливі і відповідальні 3 усіх рішень які приймаються керівником. Саме вони визначають потенціал організації і тому їм слід приділяти пріоритетну увагу [1, с.63, 3, с. 36].

ТОВ «Моспінське вуглепереробне підприємство» здійснює збагачення рядового вугілля марки $\mathrm{T}$ i вугілля газових марок $\Gamma$, ДГ 3 метою одержання концентрату для пилоподібного спалювання на теплових електростанціях. Застосовуються такі способи збагачення: важко середовищне збагачення, відсадження. Основні споживачі концентрату: «Східенерго», «Дніпроенерго», «Західенерго».На фабриці використовуються сучасні технології збагачення енергетичного вугілля. Для поліпшення конкурентоспроможності на підприємстві було освоєно збагачення рядового вугілля марок «ДГ», «Г» i антрацитів. Річна виробнича потужність: 2 млн. 500 тис. тонн рядового вугілля. Також до складу підприємства входить дільниця «промислового залізничного транспорту», що виконує комплекс робіт 3 перевезення вантажів, розставляння та пересування вагонів, навантаження та розвантаження вантажів, 3 внутрішніх та технологічних перевезень. В сучасних умовах керівництво розуміє, що одним з ключових елементів економічного успіху на підприємстві $\epsilon$ ефективна оцінка, відбор та управління кадровим потенціалом. Саме тому на підприємстві високо цінується професійний 
досвід, глибокі знання і прагнення людей до самовдосконалення, що відіграє величезну роль у продуктивності праці.

Підтримання необхідного рівня, а також розвиток трудового потенціалу викликає необхідність його регулярної оцінки ТОВ «Моспінське вуглепереробне підприємство» прикладає зусилля для ефективної роботи у сфері оцінки та відбору персоналу. Цей процес передбачає спрямування зусиль для формування кваліфікованого та компетентного штату підприємства[3, с. 40-42].

Підприємство - це не лише колективний інструмент, а й мініатюрне суспільство. Його можна уявити одночасно у вигляді штучної (адже воно створено людиною) та природною системою. Як кожна природна система , підприємство має здатність до еволюції. Однією з вирішальних частин цієї здатності є людські ресурси[3, c.27-28]. Тому при оцінці трудового потенціалу підприємства необхідно виділяти кваліфікаційний, соціальний і мотиваційний потенціал персоналу.

Таким чином, трудовий потенціал $є$ комплексною категорією, найбільш повно характеризує участь людини в процесі праці. Однак на сьогоднішній день склалася безліч точок зору на розуміння сутності трудового потенціалу, що ускладнює його вивчення. Структура трудового потенціалу представлена значним числом компонентів, 3 яких не сформована єдина система, що також ускладнює його вивчення та оцінку. Фактори формування трудового потенціалу підприємства за групами і рівнем впливу $\epsilon$ базою для його оцінки.

Формування дієвої та ефективної методики оцінки трудового потенціалу підприємства утруднено 3 тієї причини, що він характеризується значною кількістю компонентів, для яких, у свою чергу, не існує єдиної методики розрахунку, тому методи оцінки трудового потенціалу носять в основному невизначений характер. Крім того, збір інформації, необхідної для аналізу та оцінки трудового потенціалу, особливо його якісних характеристик, $є$ трудомістким процесом і вимагає спеціальних досліджень.
Проаналізувавши діяльність ТОВ «Моспінське ВПП» щодо застосування методів оцінки та відбору персоналу було визначено, що вона відбувається 3 позиції формування трудового потенціалу підприємства за поширеними оцінками, використовуючи заздалегідь спрощений та частково економічний методи які дають різноманітну характеристику персоналу i представляються різнорідними показниками, які можуть змінюватися різно спрямовано, що ускладнює їх використання в аналітичній роботі.

Стає зрозуміло, що наведені оцінки, які застосовуються на вищевказаному підприємстві, носять дуже спрощений характер та не відповідають навіть традиційному, простому поданню про трудовий потенціал. Сучасний підхід до оцінки трудового потенціалу повинен носити комплексний характер, відбиваючи все різноманіття його природи, при цьому бути досить простим i універсальним у використанні.

Виходячи $з$ представлених міркувань, оцінку стану трудового потенціалу підприємства доцільно виконувати, спираючись на основні положення збалансованої системи показників (ЗСП),яка трансформу $\epsilon$ стратегію, сформульовану керівниками та власниками організації, в завдання і конкретні показники, згруповані за різними напрямками [5, с.92-93]. Загальна стратегія, проміжні цілі та конкретні показники, що характеризують ступінь їх реалізації, формують ланцюг причиннонаслідкових взаємозв'язків.

Але наскільки авторитарною не була б організація, вона повинна задовольняти амбіції і потреби своїх членів і робити це по відношенню до них як до індивідів [1, с.64].

Керівництво організації може розробити чудові плани і стратегії, знайти оптимальні структури і створити ефективні системи передачі та обробки інформації, встановити в організації саме сучасне обладнання і використовувати самі сучасні технології. Але все це буде зведено на нівець, якщо всі члени організації не будуть працювати належним чином, не будуть своїм 
трудом сприяти досягненню організацією своїх цілей і виконанню своєї місії.

Готовність i бажання персоналу виконувати свою роботу являються одним 3 ключових факторів успіху функціонування організації. Таким чином стає зрозуміло, що шлях до ефективного керування персоналом лежить через розуміння його мотивації. дії людини.

Мотив - це те, що викликає визначені

Мотивація - це сукупність внутрішніх i зовнішніх рухомих сил, які спонукають людину до діяльності, завдають кордони і форми діяльності і надають цієї діяльності спрямованість, орієнтовану на досягнення визначених цілей. Тільки знаючи те, що мотивує людину, що спонукає пї до діяльності, які мотиви лежать в основі іiї дій, можливо розробити систему мотивації, яка буде сприяти підвищенню ефективності використання трудового потенціалу підприємства.

У зарубіжній та вітчизняній науковій літературі висвітлені різноманітні концепції та підходи щодо розробки та удосконалення системи мотивації, а саме через виконання ключових показників ефективності КРІ.

KPI (Key Performance Indicators) переклад 3 англійської „ключовий показник ефективності". КРІ дозволяє здійснювати контроль активності через систему ключових показників ефективності. Ключові показники ефективності - це показники, які максимально характеризують результати діяльності підрозділу (ступінь досягнення мети) і впливають на мотивацію персоналу.

Вона складається з трьохпідсистем:

- матеріальна мотивація;

- нематеріальна мотивація;

- персональна відповідальність і контроль.

Підсистема матеріальної мотивації містить стимули, спрямовані на задоволення матеріальних потреб і включає: премії i матеріальне заохочення співробітників; оптимізован ібазові оклади; наявність соціального пакету. Підсистема нематеріальної мотивації складається 3: кар'єрного зростання; професійного зростання i розвитку. Для створення підсистеми відповідальності і контролю розробляється

комплекс

ключових показників діяльності компанії і робиться їх "прив'язка" до керівників підрозділів i кінцевих виконавців. Створення такої системи потрібне, щоб фокусувати роботу кожного співробітника на досягнення поставлених цілей.

Характерною рисою КРІ $є$ система, яка використовується для досягнення головних цілей будь-якого бізнесу, таких як залучення і утримання споживачів (клієнтів), зростання професіоналізму співробітників, збільшення доходів і зниження витрат. Особливістю мотивації персоналу на базі KPI, $\epsilon$ орієнтація на досягнення довгострокових i короткострокових цілей підприємства, мотивація на виконання посадових обов'язків самого працівника. Як слід, поліпшення ефективності роботи працівника відкриває гігантські можливості для збільшення продуктивності праці та отримання більш високих результатів для самого підприємства.

Таким чином, шляхом використання на промислових підприємствах системи мотивації на базі КРI можливо відновити основні функції заробітної плати, підвищити мотиваційний та трудовий потенціал працівників цих підприємств, їх зацікавленість у зростанні ефективності індивідуальної та колективної праці.

\section{Висновки 3 дослідження i перспективи, подальший розвиток у даному напрямку.}

Отже, зважаючи на провідну роль промислових підприємств як базової галузі економіки нашої держави, та зміни частково форми власності, а також коригування адміністративно-командних методів управління підприємствами на порядку денному необхідні розробки варіантів впровадження не тільки використання в процесі управління підприємством сучасних економічних досліджень. Вважаємо за необхідне застосування сучасних методів розробки стратегій оцінки i відбору персоналу, а також впровадження на них мотиваційних систем як засобів підвищення ефективності використання трудового потенціалу підприємства. передувало поглиблене Цьому вивчення 
теоретичних та методологічних положень, закономірностей i принципів науки i практики управління,часткове залучення щодо оцінки та відбору персоналу, а також мотиваційних підвищенню систем які сприятимуть потенціалу підприємств промислової галузі.

\section{Список використаних джерел}

1. Друкер,Питер, Ф. Энциклопедия менеджмента.: Пер. с англ.-М.: Издательский дом «Вильямс», 2004. - 432с.: ил. - Парал. тит. англ.

2. Базаров,Т.Ю. Управление персоналом [Текст]: Т.Ю.Базарова. -М.:ЮНИТИ, 2006.$560 \mathrm{c}$.

3. Крушельницька, О.В. Управління персоналом [Текст]: навч. Посібник/ О.В. Крушельницька, Д.П. Мельничук, - К.: Кондор, 2003. - 296с.

4. Линенко, А. В. Сутність й аналіз трудового потенціалупідприємства за показникамиефективностійоговикористання [Текст] / А. В. Линенко, О. Л. Шевченко // Держава та регіони. Серія: Економіка та підприємництво. - 2008. - № 4. - С. 111-116.

5. Каплан Роберт С. Сбалансированная система показателей. От стратегии к действию [Текст]: пер. с англ. / Роберт С. Каплан, Дейвид П. Нортон. - М.: ЗАО «ОлимпБизнес», 2007. - 320 c.

6. Колесень, Е. В. Оценка трудового потенциала промышленного предприятия [Текст] / Е. В. Колесень // Вестник Пермского университета. - 2012. - Сер. «Экономика». Вып. 1(12). - С. 112-119.

Дикань Валерія Володимирівна, д.е.н., професор кафедри менеджменту і адміністрування Українська державна академія залізничного транспорту. Тел. (057)730-10-46 E-mail: valeriya@hotbox.ru

Шаповалов Юрій Олександрович, Магістрант

Dykan Valeriia Volodymyrivna, d.e.s., professor department of management and administration Ukrainian State Academy of Railway Transport.Tel.: (057)730-10-46 E-mail: valeriya@ hotbox.ru

Shapovalov Yuriy Oleksandrovuch, Master's Student 